\title{
The Future of European Values
}

\section{El futuro de los valores europeos}

\author{
AC Grayling ${ }^{1}$ \\ New College of the Humanities, London; St. Anne's \\ College, Oxford (England)
}

Recibido: 31-08-20

Aceptado: 24-09-20

\begin{abstract}
The EU's values of transnational peace, cooperation, secularism, rationality, and protection of civil liberties and human rights are amongst the most valuable legacies of the Enlightenment. The European project has weathered several crises in the first third of the 21 st century, including a change of political direction in the United Kingdom. Brexit is viewed as a consequence of the UK's flawed electoral system, exposed as susceptible to hijacking by militant and disruptive minorities. The future of European values must be protected from politically unreliable systems such as the UK's FPTP.
\end{abstract}

Key-words: Enlightenment, European Union, Secularism, Brexit, FPTP.

\section{Resumen}

La Unión Europea se fundamenta en la cooperación pacífica entre naciones, así como en la razón, el secularismo y la protección de los derechos humanos y las libertades individuales. Todos ellos son valores propios de la Ilustración. El proyecto europeo ha sufrido varias crisis en el primer tercio del siglo XXI, entre ellas la salida del Reino Unido del club comunitario. El Brexit

${ }^{1}$ A. C. Grayling CBE MA DPhil (Oxon) FRSA FRSL is the Master of the New College of the Humanities, London, and its Professor of Philosophy. He is also a Supernumerary Fellow of St Anne's College, Oxford. He is the author of over thirty books of philosophy, biography, history of ideas, and essays. He was for a number of years a columnist on the Guardian, the Times, and Prospect magazine. He has contributed to many leading newspapers in the UK, US and Australia, and to BBC radios 4, 3 and the World Service, for which he did the annual 'Exchanges at the Frontier' series; and he has often appeared on television. He has twice been a judge on the Booker Prize, in 2014 serving as the Chair of the judging panel. He is a Fellow of the Royal Society of Arts, a Fellow of the Royal Society of Literature, a Vice President of Humanists UK, Patron of the Defence Humanists, Honorary Associate of the Secular Society, and a Patron of Dignity in Dying. His two most recent books are 'The History of Philosophy' (2019) and 'The Good State' (2020). https://en.wikipedia.org/wiki/A._C._Grayling 
se explica como una consecuencia de la vulnerabilidad del sistema electoral británico, cuya circunscripción electoral individual por mayoría simple es poco representativa y fácilmente manipulable por minorías militantes y rupturistas. El futuro de los valores europeos debería protegerse de sistemas políticos poco fiables como el first past the post británico.

Palabras-clave: Ilustración, Unión Europea, Secularismo, Brexit, Sistemas Electorales.

Great historical movements have their advances and setbacks, they take time, they do not reach a terminus but always only a new phase. In half a century of patient growth, the imaginative, co-operative European endeavour initiated in the devastations of the post-World War Two grew to become the European Economic Community and then, in the 1990s, the European Union. It weathered several crises as the first quarter of the twenty-first century unfolded; one was the difficulties experienced by weaker southern European economies in the Eurozone, the other was the turbulence caused by changes of internal political direction in Poland, Hungary and most notably the United Kingdom.

The last of these contains a major lesson for the EU, and one of the key adjustments required for its continued progress in the future. I explain this vital point below. First, it is important to remind ourselves why the EU project matters so much, and what this importance consists in.

The 'EU Values' statement on the website of the European Parliament rightly gives emphasis to the rights and freedoms of the citizen and the rule of law. The desiderata of peace, co-operation and the protection of civil liberties and human rights equally for all, lie at the heart of the European ideal. Cooperation between the nations of Europe, with the four freedoms of movement for capital, goods, services and people, aims at prosperity, the surest guarantor of stability and peace. The desire for peace, and the desire to have human rights respected, both arise from Europe's own bitter history: these are not soft, vague aims, but the fruits of the hardest experience of suffering.

The EU offers an example to the world of how states and nations can come together and work together to build something of immense good for their citizens. In the co-operative effort it has come to stand as a mighty third centre of global power. But whereas the other two centres - the US and China retain what are fundamentally nineteenth century ideas about the association of economic and military power and the rivalries these necessitate and feed upon, the EU example is of a different way the world can be. It is no accident that in South Asia, South America, Africa, efforts are being made to created regional versions of the EU in order to benefit from the selfsame co-operative model. 
The two great and rather different examples set by Europe in regard to the sources of the EU idea are the history of its wars, and the Enlightenment. In the seventeenth and twentieth centuries Europe tore itself apart in devastating conflicts. Following the Treaties of Westphalia in 1648, their adjustment and iteration at the Congress of Vienna after the Napoleonic epoch, and the end of a period of war intermitted by uneasy peace between 1914 and 1945, Europe made efforts to reset its arrangements to prevent recurrence. One might say that the Cold War stand-off of the period to 1989 helped Western Europe lay the foundations of the EU ideal, because there was no quick return to complacency and short-term memory after 1945, given the ominous possibility of conflict that still remained.

A richer, deeper, more significant source of the EU ideal is the Enlightenment. As this immensely important development is itself a panEuropean phenomenon, and one of the greatest gifts to history, it is worth dwelling on it in more detail.

The Enlightenment is the movement of thought in seventeenth and eighteenth century Europe - and Europe's large outpost of North America that put reason in the place of faith as a means of understanding the world and governing human affairs, championed the rights of the individual, advocated rational methods seeking solutions to social and political problems, promoted science, and opposed absolute monarchy and the power of organized religion, seeing both as barriers to human progress. The watchwords of the Enlightenment were rights, tolerance, freedom of thought, science, and the 'social contract' as the basis of political society.

It is possible to say that the Enlightenment covers the whole period from the Reformation in the sixteenth century until our own day, despite reversals and setbacks and the various vigorous 'counter-Enlightenments' responsible for them, because the scientific revolution and the retreat both of absolutism in government and the conservative tendencies of organised religion in education and social policy were important factors in the conditions that have transformed life and society to produce the advanced liberal democracies of the world.

The Enlightenment is a web of ideas and influences. When the sixteenth century Reformation weakened the power of religion to control what could be investigated and published, especially in the Protestant parts of Europe, science and philosophy flourished. A number of outstanding individuals contributed to the process. In the sixteenth century itself, Copernicus and Montaigne were among the auguries of what was to come. The seventeenth century saw Descartes, Bacon, Grotius, Hobbes, Spinoza, Locke, Leibniz, Malebranche and Bayle in philosophy, and in science it saw Mersenne, Pascal, Galileo, Gassendi, Huygens, Kepler, van Leeuwenhoek, Hooke, Wren, Boyle, Newton, Tradescant and Lyte. The eighteenth century's luminaries included Voltaire, Montesquieu, 
Hume, Leibinz, Rousseau, Kant, Priestley, Lavoisier, Linnaeus, and more. At the end of the century the rising star of Goethe reminds us that through the centuries of the Enlightenment, from Shakespeare onwards, the literature of the period was an efflorescence of genius that carried the new spirit of the age into minds of Europe, from the eastern shores of North America to the Urals. So too did painting and music, architecture, landscape and gardening: the arts of civilisation in general.

Under the influence of the rise of science the philosophes of France, not least among them the encyclopaedists Denis Diderot and Jean le Rond d'Alembert, together with Voltaire, undertook their respective great projects of reforming the world by the light of reason. They and all the others mentioned did not think in national terms, but in global terms; their ideas were for all Europe, all the world.

The classic definition of the concept of 'enlightenment' in this historical context is to be found in an essay entitled 'What is Enlightenment?', published in 1784, by one of the movement's greatest representatives, Immanuel Kant. He wrote, 'Enlightenment is man's emergence from his self-imposed immaturity. Immaturity is the inability to use one's understanding without guidance from another. This immaturity is self-imposed when its cause lies not in lack of understanding, but in lack of resolve and courage to use it without guidance from another. Sapere Aude! (Dare to know) - "Have courage to use your own understanding!" - that is the motto of enlightenment.'

Neither Kant nor any of his contemporaries believed that they had attained enlightenment; they meant that they were making progress towards it. Kant remarked, 'If it is now asked, "Do we presently live in an enlightened age?" the answer is, "No, but we do live in an age of enlightenment" - that is, the darkness of ignorance and oppression is lifting, the dawn has begun.

In describing the immaturity of the intellect as consisting in need for guidance by another, Kant expressly attacked the authorities who sought to keep the human mind in a state of subordination - to authority or dogma, or both. The intellect needs liberty in order to mature, but in every aspect of life, he wrote, liberty was lacking. 'Nothing is required for enlightenment except freedom; and the freedom in question is the least harmful of all, namely, the freedom to use reason publicly in all matters. But on all sides I hear: "Do not argue!" The officer says, "Do not argue, drill!" The tax man says, "Do not argue, pay!" The pastor says, "Do not argue, believe!"”

The iconic work of the Enlightenment is unquestionably the Encyclopédie of Diderot and d'Alembert. One of their principal targets in attempting to free the mind of humanity was religion. 'In vain, oh slave of superstition,' says Nature to Mankind in Diderot's Supplement to Bougainville's Voyage, 'have you sought your happiness beyond the limits of the world I gave you. Have 
courage to free yourself from the yoke of religion . . . Examine the history of all peoples in all times and you will see that that we humans have always been subject to one of three codes: that of nature, that of society, and that of religion - and that we have been obliged to transgress all three in succession, because they could never be in harmony.' The result is, said Diderot, that there has therefore never been 'a real man, a real citizen, a real believer.'

Although the repudiation of religion's hegemony over thought was important it was not the sole concern, but rather the starting point for the project of encouraging each individual to think for himself or herself, to rely on reason, and to apply the lessons of science as a guide to building good lives and good societies. The Enlightenment project was accordingly a creative and reforming endeavour, based on the idea of freedom and rights.

The Enlightenment has of course always had admirers and detractors either too enthusiastic or too hostile respectively, not least among the latter those detractors who blame it for everything from Robespierre's Terror to Nazism and Stalinism. In fact the horrors of human history since the French Revolution have largely been the result of counter-Enlightenment outlooks. Where Enlightenment thinkers argued for the autonomy of the individual and the rights of man - jointly implying a pluralistic society - and accorded authority to reason and science rather than kings and priests, very different things were extolled by the various counter-Enlightenment movements, chief among them social and political Romanticism with its offspring of nationalism, racism, and the praise of war, encouraging the totalitarianisms which attempted to revive the kind of absolutism once exercised by church and monarchy.

As this shows, the various forms of counter-Enlightenment have been just as significant for recent history as the Enlightenment itself. Contemporary opposition came from those who disliked the implications of Enlightenment thought for the pre-existing status quo; fiercer opposition came later from those who experienced those implications actually bearing fruit in the nineteenth and twentieth centuries in the form of increased democratic participation and freedom of thought. Thus it is that the Enlightenment is seen as indictable for the excesses of the French Revolution, as meriting the Romantic reaction to its rationalism and formalism, and as the ultimate source of both Fascism and Stalinism. There are even those who, this time rightly, recognize that it is responsible for 'liberal' values, but who think this is a bad thing (they paradigmatically include conservative Americans for whom 'liberal' is a pejorative term denoting someone who poses a threat to 'family values', the unrestricted freedom of the market, and the right to own guns). And of course it remains a bête noir for all who see it as challenging what they think matters most to the human spirit in its need for encounters with the mystical, the ineffable, the numinous, and the divine. 
The Enlightenment's first opponents were of two broad kinds: those we would now describe as politically right-wing - ranging from clergymen to thinkers like Edmund Burke and Joseph de Maistre - and those we now call Romantics, for whom imagination, nature and emotion are more important than what they regarded as the Enlightenment's reductive and mechanical rationalism.

Burke argued that the Enlightenment's attack on tradition and religion - for him the respective sources of legitimacy in matters political and moral - were the direct cause of everything bad about the French Revolution. He vigorously opposed the Enlightenment's claim that the ultimate source of political authority is the people. For the philosophes of the Enlightenment the idea that the people must have a say in the government of the state was simply obvious, and it has proved to be (despite Burke and later conservatives) the underpinning of liberal democracy since. But in the eighteenth century the word 'democracy' was a term of opprobrium, and 'the people' were regarded as anarchic and dangerous.

Romantics treated the Enlightenment's espousal of science as implying that scientific progress is the only kind of progress there is, and that history and human experience can only be understood in mechanistic, even deterministic terms. Recoiling from this supposed view, the Romantics placed emotion above reason, and celebrated the subjective, the visionary, the personal, and the nonrational. They saw moods and passions as sources of insight and truth, and gave first place in their praises to such experiences as the individual's passionate reaction to natural beauty. This is in a way odd, for Enlightenment attitudes are natural successors of the classical admiration for order, balance and harmony in music, architecture, art and poetry. That is a valid aesthetic, even if it is not the whole story. Romanticism deliberately contrasted this aesthetic with another applauding the spontaneous and various, trusting emotions to discover better principles of beauty and excellence than reason can.

Of course one would not wish to be without the best of either the Enlightenment or the Romantic legacy. But it is worth insisting that the uncritical embrace of Romanticism aided the survival of many shibboleths that the Enlightenment sought to extirpate - for a chief example, superstition.

A famous later critical reaction to the Enlightenment illustrates how its optimistic and progressive outlook came to be seen by critics in an opposite light. In The Dialectic of Enlightenment, whose authors Max Horkheimer and Theodore Adorno said began as a conversation between them in a New York kitchen during the worst days of the Second World War, the argument is that the ideas and principles of the Enlightenment had metamorphosed into their opposites. The Enlightenment extolled individual freedom, but it had become a form of enslavement by economic forces. Science was urged as the rational 
alternative to religion, but 'scientism', itself assuming the guise of a salvation myth promising scientific explanations and solutions for everything, simply replaced religion and came to exert the same maleficent influence.

Horkheimer and Adorno regarded their attack on scientific rationality as their key argument, because they thought they were witnessing, in the horrors of the Second World War, the realization of its malign threat. The philosophes of the eighteenth century believed that the objective character and pragmatic success of science would promote the interest of freedom and tolerance. But Horkheimer and Adorno argued that scientific rationality has its own dynamic, which gradually makes it turn against the values which facilitated its own rise. It therefore changes from being a weapon against repression into a weapon of repression. Believing its dreams of progress, drunk on its successes, triumphantly increasing its mastery over nature, Enlightenment's chief ornament - scientific rationality - becomes a nightmare, and everything it had set out to destroy re-emerges in new and worse forms - chief among them, so Horkheimer and Adorno argued, Fascism.

The analysis offered by Horkheimer and Adorno was greatly influential in the Frankfurt School, whose debates were widely followed in the years after the Second World War. It does not however survive scrutiny. They saw the idea of scientific mastery over nature as leading to the idea of totalitarian mastery over people, a mastery exercised by those into whose hands the levers of power, both economic and political, had been put by the material progress that the Enlightenment made possible. As they put it, 'instrumental rationality' had become 'bureaucratic politics', and the worst form of the latter was Nazism.

But the implausibility of this is obvious. Nazism drew its strength from the peasantry and petit-bourgeoisie, the people who felt most threatened by capital's advance to power. Horkheimer and Adorno misidentified the true source of the new oppression: the descendants, so to speak, of the people who originally had most to lose from Enlightenment and therefore reacted with hostility to it - namely, and literally, the reactionaries. If Nazis had lived in the eighteenth century, they would have defended absolute government against the 'instrumental rationality' which then expressed itself as aspirations to secular democracy. And so, indeed, would Stalinism, of which Horkheimer and Adorno were not so critical - though by their own argument they should have been.

Just as Horkheimer and Adorno were not the first to attack the Enlightenment, they were not the last. Postmodernism denies the very premises of the Enlightenment's 'grand narratives', and the institutionalized opposition to Enlightenment embodied in the very nature of most religious and some major political outlooks remains. The project of championing the Enlightenment cause, therefore, remains likewise.

What people mean today by 'Enlightenment values' - by the values of the 
EU - is an updated and somewhat idealized, but no less valid and admirable, version of the values that the eighteenth- century Enlightenment embodied. They can be listed as a set of commitments: to pluralism, individual autonomy, democracy, the rule of law, tolerance, science, reason, secularism, equality, the value of education, and the promotion and protection of human rights and civil liberties. None of these are mere abstractions, and the difference they make to the lives of individuals is vast. Only compare the life of the ordinary man and woman in a Western country today with the lives of their forebears three or four centuries ago, or with many of their fellows today in developing countries. The transforming effect of Enlightenment ideas in history is plain to see: and as admirable as it is plain. It is written into the documents of the EU, into its aspirations, and into its practices. The EU is arguably one of the greatest fruits of the Enlightenment, harvested from the bitter droughts and frosts of war and atrocity that finally made the people of Europe stand up in determination to change history.

As mentioned at the outset, one of the chief setbacks experienced by the EU project in the first quarter of the twenty-first century was the phenomenon of Brexit, the UK's leaving the EU. And as also mentioned, this occurrence teaches an important lesson about what the EU must require of its member states henceforth: namely, genuinely representative democratic practices, most especially electoral systems that properly represent the diversity of opinion and preference in the electorate. Given that almost all EU member states have such systems, this might seem a surprising thing to say. But the $\mathrm{UK}$ is an egregious example of a system in which the highly unrepresentative nature of the electoral system can result - an in the UK's case did result - in highly partisan government acting in factional as opposed to national interests. 'Brexit' is the disruption to the EU project that resulted from this failing in the UK constitutional order.

Two facts illustrate this. In the 2016 referendum on whether the UK should continue its membership of the EU, $37 \%$ of the total electorate voted in favour of leaving the EU. Because the referendum was technically 'advisory only', no threshold or supermajority requirement had been put in place; for so consequential a matter, either would have been the least safeguard required. Because of the turnout, the $37 \%$ vote constituted $51.89 \%$ of actual votes cast. In the 'first past the post' (FPTP) system of British parliamentary elections, a mere majority of votes cast, whether or not it is a true majority of electors, is enough.

The second fact is that in the general parliamentary election of December 2019, the Conservative Party under Boris Johnson won an 80 seat majority over all other parties in the House of Commons. This large majority was secured 
on $29 \%$ of the total electorate, represented by $43 \%$ of actual votes cast - in neither case a majority, but resulting in a massive preponderance in the House of Commons rendering that body ineffective as a control on the government.

These astonishingly undemocratic outcomes are the artefact of the FPTP electoral system. Its undemocratic nature is sufficiently attested by the foregoing examples, but a model conclusively demonstrates the problem. Consider a voting district consisting of 100 electors. Suppose ten candidates offer themselves, eight of them securing ten votes each, one of them nine votes, and the last of them eleven votes. By FPTP the winner is he who secured eleven votes, leaving the other 89 electors unrepresented. In actual elections, in every constituency more than two candidates typically stand; the 'winning' candidate therefore typically represents a minority of the voters.

In the UK the majority of the electorate has always either been in favour of, or accepting of, EU membership. Leaving the EU has never, in any actual vote or in any opinion poll, commanded more than $37 \%$ of the total electorate. And yet the economically and diplomatically damaging mistake of Brexit, primarily a project of a small group of individuals hostile to the EU project and wishing to protect their own interests against (for example) EU regulations on offshore tax legislation, succeeded first in influencing, and then controlling, the government of the UK through the dysfunctional system of representation which it has proved too easy to manipulate.

It matters that what happened in the UK's EU membership referendum should be understood so that in future a vital provision is observed for any state's qualifying for EU membership. The following points and their implications are more fully discussed in my books Democracy and its Crisis (London 2017) and The Good State (London 2019).

The UK's EU referendum franchise excluded - after discussion of the matter prior to introduction of the Referendum Bill in the UK Parliament in 2015 - three important constituencies: 16 and 17 years olds, expatriate British citizens who had lived abroad for more than a certain number of years, and EU citizens resident in the UK and paying their taxes there. It would seem obvious that all three groups should have been included as having the most material interest in the outcome of the vote. In the franchise for the Scottish independence referendum of 2014, 16-17 year olds had the vote and so did EU citizens resident in Scotland.

As mentioned, no threshold was specified for the outcome of the referendum, unlike the 1979 Scottish devolution referendum which required that $40 \%$ of the electorate should be in favour for any change to take place. In Briefing Paper 07212 published on 3 June 2015 all Members of Parliament were told that the referendum was advisory only, and would not be binding on Parliament or government. This point was iterated viva voce by the Minister 
for Europe in the debate in the House of Commons later that same month. This was the reason given for not including a threshold and for not extending the franchise appropriately.

The outcome of $37 \%$ of the restricted electorate voting to leave the EU was by any standards insufficient to justify a constitutional change so significant as the UK's exiting the EU. There is scarcely any civilized state in the world where a simple majority, let alone a small one, would permit this: for such a change, a supermajority would be required, of $60 \%$ or perhaps even $66 \%$ either of votes cast or the entire electorate. Yet a small minority of actual votes cast, representing not much more than one third of the UK electorate, was taken by Brexiter politicians as not merely justifying but mandating the actions they took following the referendum. There was therefore nowhere near enough justification or legitimacy for a Brexit to occur.

The Brexit ministry empanelled after the referendum sought to trigger Article 50 of the Lisbon Treaty notifying EU partners of an intention to leave the EU, without a Parliamentary debate. It had to be taken to court to oblige it to respect the constitutional sovereignty of Parliament. In response, and arguably in contempt both of what is meant to be Parliament's role in of the intention of the Supreme Court judgment, the government introduced a very short Bill of a few lines to hasten through Parliament, with restricted time to discuss it, and a full three-line whip to ensure that its own MPs, whatever their real views, would vote for triggering Article 50 despite any argument, facts, considerations or warnings that might be put forward in the hurried debate.

It is relevant to recall that the $2016 \mathrm{EU}$ referendum was not necessitated by any crisis in the EU or in the UK's relations with its EU partners; there were no threats or problems arising from EU membership, other than those alleged (and alleged for over 40 years of anti-EU activism) by 'Eurosceptics' and politicians on the right wing of the Conservative Party and UKIP. Calling the referendum was in fact an effort by the then leadership of the Conservative Party to stifle a long-standing quarrel within that Party. During the previous government David Cameron had promised a referendum, against the advice of his senior colleagues, to silence the far right of his Party, which was engaged in its usual procedure of making life difficult for him as they had done with every Conservative Prime Minister since 1972.

Cameron almost certainly did not expect to win the election of 2015, still less with an outright majority. He had offered the referendum as one might offer a bone to quieten barking dogs. When he won a majority in the election, he was obliged to honour the promise. Neither he nor anyone else, including the proBrexit camp, expected Leave to 'win', so he culpably allowed the Brexit faction to arrange the franchise in a way that best suited them - this being the exclusion of 16-17 year olds (Cameron subsequently said that insisting on their inclusion 
would have made too much trouble with his right wing), expatriates, and EU taxpayers in the UK, who between them would have assured a significant Remain majority, a fact the Brexiters well understood. Deliberate restriction of the franchise is gerrymandering: the EU referendum was gerrymandered.

Likewise no-one asked the Brexiters to produce an account of what would follow if a Leave vote won: there were no details, no manifesto, only one apparent promise - the EU subvention to be dedicated to the National Health Service - and otherwise a raft of misleading claims and false statements and slogans, as has since become public knowledge.

All these points illustrate how a major political event in the UK exposes the sham of the constitutional arrangements, so easily and readily manipulated by the executive for highly partisan ends, and however damaging to the polity and populace as a whole. No constitutional system should allow a partisan group to hijack the interests of the whole.

This, then, is the lesson that the EU has to apply henceforth: all member states of the EU must have proportional systems of electoral representation. When the UK, or former component nations of the UK should it break up following Brexit - a genuine likelihood - reapply for membership of the EU, as is inevitable, one condition of re-admittance must be reform of the electoral system to render it properly representative. Without genuine democracy a country is politically and diplomatically unreliable and unstable and potentially disruptive, as the UK has been.

The EU's values of peace, co-operation and the protection of civil liberties and human rights equally for all, are powerful ones. They are a bright signal for the future not just of Europe and its peoples but for the world. They mark what is the better way for humanity. The great hope is that they will prevail, and that the rest of the world will follow the lead thus set. 
